\title{
Three exceptionally strong East-Asian summer monsoon events during glacial times in the past $470 \mathrm{kyr}$
}

\author{
D.-D. Rousseau ${ }^{1,2}$, N. Wu ${ }^{3}$, Y. Pei ${ }^{3}$, and F. $\mathbf{L i}^{3}$ \\ ${ }^{1}$ Ecole Normale Supérieure de Paris, Laboratoire de Météorologie Dynamique (UMR INSU/CNRS 8539), and CERES-ERTI, \\ 24 rue Lhomond, 75231 Paris cedex 5, France \\ ${ }^{2}$ Lamont-Doherty Earth Observatory of Columbia University, Palisades, NY 10964, USA \\ ${ }^{3}$ Key Laboratory of Cenozoic Geology and Environment, Institute of Geology and Geophysics, Chinese Academy of \\ Sciences, Beijing 100029, China
}

Received: 14 November 2008 - Published in Clim. Past Discuss.: 22 December 2008

Revised: 14 April 2009 - Accepted: 14 April 2009 - Published: 23 April 2009

\begin{abstract}
Chinese loess sequences are interpreted as a reliable record of the past variation of the East Asian monsoon regime through the alternation of loess and paleosols units, dominated by the winter and summer monsoon, respectively. Different proxies have been used to describe this system, mostly geophysical, geochemical or sedimentological. Terrestrial mollusks are also a reliable proxy of past environmental conditions and are often preserved in large numbers in loess deposits. The analysis of the mollusk remains in the Luochuan sequence, comprising L5 loess to S0 soil, i.e. the last $500 \mathrm{ka}$, shows that for almost all identified species, the abundance is higher at the base of the interval (L5 to L4) than in the younger deposits. Using the present ecological requirements of the identified mollusk species in the Luochuan sequence allows the definition of two main mollusk groups varying during the last $500 \mathrm{kyr}$. The coldaridiphilous individuals indicate the so-called Asian winter monsoon regime and predominantly occur during glacials, when dust is deposited. The thermal-humidiphilous mollusks are prevalent during interglacial or interstadial conditions of the Asian summer monsoon, when soil formation takes place. In the sequence, three events with exceptionally high abundance of the Asian summer monsoon indicators are recorded during the L5, L4 and L2 glacial intervals, i.e., at about 470, 360 and $170 \mathrm{kyr}$, respectively. The L5 and L4 events appear to be the strongest (high counts). Similar variations have also been identified in the Xifeng sequence,
\end{abstract}

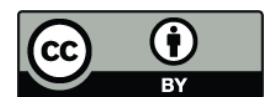

Correspondence to: D. D. Rousseau (denis.rousseau@1md.ens.fr) distant enough from Luochuan, but also in Lake Baikal further North, to suggest that this phenomenon is regional rather than local. The indicators of the summer monsoon within the glacial intervals imply a strengthened East-Asian monsoon interpreted as corresponding to marine isotope stages 12,10 and 6, respectively. The L5 and L2 summer monsoons are coeval with Mediterranean sapropels S12 and S6, which characterize a strong African summer monsoon with relatively low surface water salinity in the Indian Ocean. Changes in the precipitation regime could correspond to a response to a particular astronomical configuration (low obliquity, low precession, summer solstice at perihelion) leading to an increased summer insolation gradient between the tropics and the high latitudes and resulting in enhanced atmospheric water transport from the tropics to the African and Asian continents. However, other climate drivers such as reorganization of marine and atmospheric circulations, tectonic, and the extent of the Northern Hemisphere ice sheet are also discussed.

\section{Introduction}

The monsoon system affects large regions of the globe and is one of the strongest features in modern atmospheric circulation. The Asian monsoon is among the best known because of the strong impacts on the large concentration of population in this region, and has two sub-branches, the Indian and the East Asian (EA) (Tao and Chen, 1987). While the Indian sub-regime is bounded to the North by the Himalayan mountains, the low-latitude air flow of EA summer monsoon penetrates northward into Southern China, with warm and moist

Published by Copernicus Publications on behalf of the European Geosciences Union. 


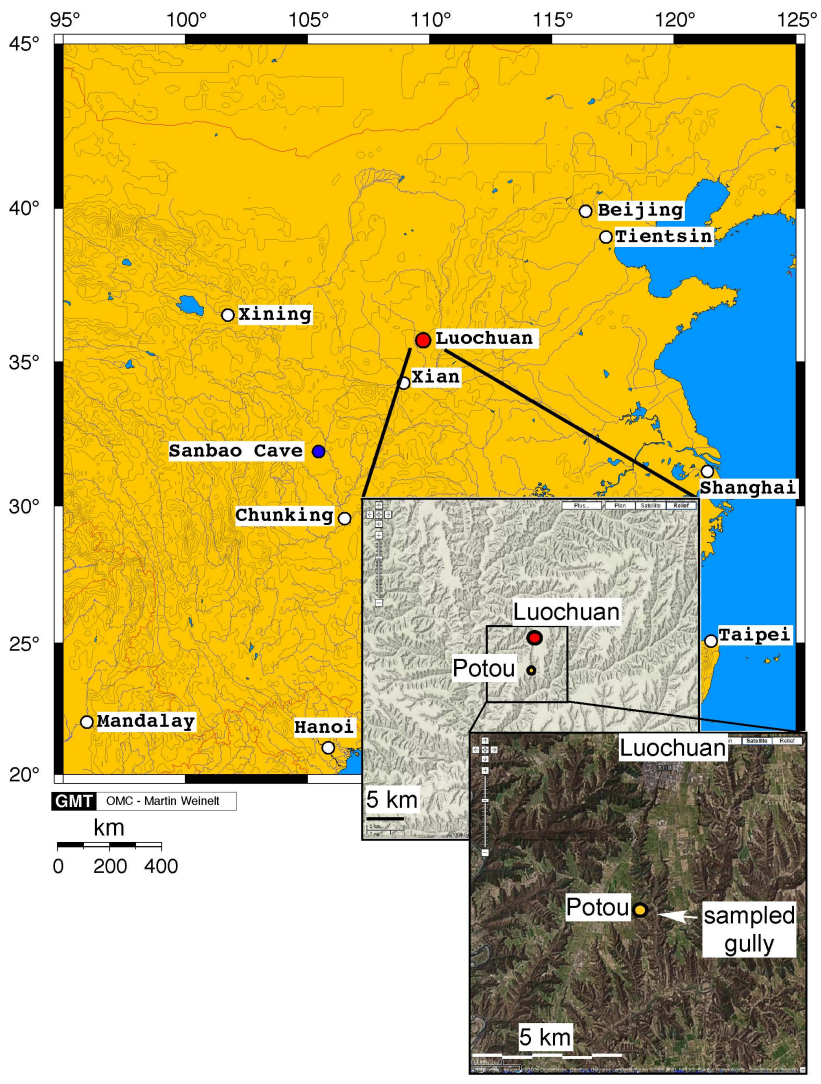

Fig. 1. Location of the Luochuan loess sequence in south Chinese Loess Plateau. (a) general map of east Asia; (b) Focus on the studied area showing the dissected loess plateau due to active erosion (Google satellite image); (c) Location of the studied sequence from Luochuan town (Detailed Google satellite image).

air reaching about $30^{\circ} \mathrm{N}$ in July (Tao and Chen, 1987). This advance of the EA summer monsoon is closely related to northward displacement of the subtropical anticyclone in the Western Pacific, with the South China sea supplying the main source of heat (Tao and Chen, 1987). Conversely, surges of cold air southward from the Asian continent, mostly from Siberia, starting mainly in October and propagating equatorward over Southern China, corresponds to the intensification of EA Hadley cell, and is known as the EA winter monsoon. Upward air motion and cloud formation then occur over the Indonesian and Malaysian maritime continent (Johnson and Houze, 1987).

Eolian deposition started about $22 \mathrm{Myr}$ ago in China (Guo et al., 2002) and since then, the loess material, mainly deposited horizontally (Liu et al., 1985, 1991), has been mostly composed of dust transported from northwestern deserts like the Takla Makan, Mu Us, or the Gobi. The Loess Plateau thus has a uniform stratigraphy, at least for its youngest part, which consists of a succession of paleosol complexes labeled $\mathrm{S}$ for soil, and L for loess units. S0 represents the present interglacial-Holocene $(12000 \mathrm{yr})$. The base of the Quater- nary sequence is dated at about 2.6 Myr (Heller and Liu, 1982; Liu et al., 1985, 1991) and overlies the Red Clay Formation, which has been demonstrated to also be of eolian origin (An, 2000; Ding et al., 1998, 1999b). The Pleistocene paleosol loess succession first shows short cycles, which reflect the $40 \mathrm{kyr}$ periodicity of the early Pleistocene (Ding et al., 2002; Kukla et al., 1990). After the Brunhes-Matuyama boundary at about $780 \mathrm{kyr}$, the length of the cycles increases during the late Middle and Upper Pleistocene to reach around $100 \mathrm{kyr}$ at about $400 \mathrm{ka}$ (Ding et al., 2002; Kukla et al., 1990). This change in cyclicity is also associated with an increase in the magnitude of the recorded climatic changes identified by the variation in magnetic susceptibility. Loess and paleosol complexes have been linked with the marine isotope stratigraphic units, corresponding to the even- and odd numbered isotope stages of the glacial-interglacials, respectively (Clemens, 1998; Rea et al., 1998). The youngest S1-L1 couplet corresponds to the last climatic cycle, and consequently to marine isotope stages (MIS) 5 to 2. Superimposed on the cyclicity of the Chinese loess sequence, some particular units are important stratigraphic markers. In mid and late Pleistocene interval, paleosol complex S5 is well developed showing at least 3 different superimposed soils, and is interpreted as a key marker (Kukla and An, 1989; Liu et al., 1985). It is related to MIS 13-15. Conversely, loess unit L9 (MIS 22-24) shows a strongly sandy facies characteristic of harsh windy conditions over the plateau (Kukla and An, 1989; Liu et al., 1985). The diversity and completeness of the record, reproducible all over the plateau, have made the Chinese loess sequences a reliable record of the Asian monsoon regime almost since its origin (Guo et al., 2002). Numerous proxies have been used to study the paleomonsoon record of these loess-paleosol sequences. Among them, low field magnetic susceptibility has been extensively used as a useful index. The high values in the paleosols characterize dominant past summer monsoon phases, while the low values within the loess units correspond to the so-called winter monsoon (An et al., 1991; Ding et al., 1993; Heller et al., 1991; Kukla et al., 1988; Kukla and An, 1989; Rutter et al., 1990).

The description of magnetic grains of bacterial origin in the soils tempered the interpretation in terms of climatic signal (Maher and Thompson, 1992, 1994; Maher, 1998; Zhou et al., 1990), leading to the use of additional indices. Grain size analysis permits a better description of the episodes of winter conditions as coarser material is interpreted to be related to stronger wind strength transporting the dust from the desert areas (Ding et al., 1995, 1999a; Porter and An, 1995; Xiao et al., 1995). This particular wind regime is associated with the occurrence of a high-pressure cell over Siberia and a low-pressure cell over the tropics in the South China Sea. The iron content measures the ratio between the liberated versus available iron in the sediment (Guo et al., 2000). This is an indicator of the degree of pedogenesis, which is controlled by the summer monsoon whose wind regime 
is associated with a warm pool in the tropical western Pacific Ocean and a cooler continent. A higher ratio indicates strengthening of precipitation.

Transported dust does not directly form loess horizons but requires trapping by vegetation (Pecsi, 1990; Hatté et al., 1998, 2001). These particular conditions permit mollusk species to live and develop (Rousseau, 1989). Terrestrial mollusks are particularly good indices of past environments and paleoclimates from loess deposits where they usually constitute the only biological remains in sufficient amount (Lozek, 1964; Puisségur, 1978; Rousseau et al., 1990). In the Chinese loess sequences, terrestrial mollusks have been found in all the Quaternary deposits (Rousseau and $\mathrm{Wu}, 1997,1999$; Wu et al., 2001), and even described within the Red Clay formations or older loess units ( $\mathrm{Li}$ et al., 2006; Wu et al., 2006). The mollusk species retrieved from the mid to late Pleistocene units still have modern representatives, and thus their respective modern ecology requirements can be used to infer past environmental conditions (Chen et al., 1985; Chen and Gao, 1987; Yen, 1939). Terrestrial mollusks can be interpreted as sensitive paleomonsoon indices, especially for the last $470 \mathrm{kyr}$ in the Luochuan sequence $\left(35^{\circ} 45^{\prime} \mathrm{N}, 109^{\circ} 25^{\prime} \mathrm{E}\right)$ due to its position near the present northern boundary of the East-Asian summer monsoon (Figs. 1, 2).

Thus far, the association of monsoon regime variations with mollusk populations has been limited to the local record. The aim of the present paper is to put the observed variations in a global context and propose a climatic scenario supporting the identified oscillations.

\section{Material and methods}

The Potou sequence, near Luochuan on the Chinese loess plateau, is a well known series, which has been extensively studied. Kukla et al. (1988), Kukla and An (1989) completed the low field magnetic susceptibility (MS) record of the whole Quaternary sequence, taking readings every 10 or $5 \mathrm{~cm}$ according to the stratigraphical horizon. The sequence investigated in the present analysis is also located near Potou, close to Kukla's studied sections. It covers the interval including top paleosol S0 to the base of Loess unit L5 corresponding to a combined thickness of $35 \mathrm{~m}$ covering the last $470000 \mathrm{yr}$ according to the Kukla and An (1989) time scale. Because of the varying outcrop accessibility, several 2-3 m wide and 2-3 m high panel sections were prepared after removing about $50 \mathrm{~cm}$ of the weathered surface material. This protocol allows the stratigraphy to be carefully identifed, and the mollusk shells preserved in the sequence can be correlated precisely with the lithology.

Every sample $10 \mathrm{~cm}$ thick corresponds to about $15 \mathrm{~kg}$ of sediment. The samples were washed and sieved locally on a $0.5 \mathrm{~mm}$ mesh to reduce their size. A second sieving under water was processed in the lab on a $0.5 \mathrm{~mm}$ mesh. The complete shells and shell fragments were counted following the protocol of Puisségur (1976). Depending on the preservation status of the shells or fragments, their ornamentation and shape allows the species identification (15 characterized) or, at minimum, the genus determination (12 identified).

Parallel with the mollusk sampling, the low field magnetic susceptibility (MS) was measured with a Bartington portable MS2 susceptibility meter every $10 \mathrm{~cm}$ in the loess units and every $5 \mathrm{~cm}$ in the soil complexes, allowing the precise identification of the transitions between different stratigraphical units. A single plotted measurement corresponds to 10 averaged readings following the same protocol applied by Kukla et al. (1988), Kukla and An (1989). The measured MS allows characterizing the different stratigraphical units identified in the field, and checking the correspondence of the observed stratigraphy with that previously defined by Kukla and An (1989) at the same location.

\section{Results}

The low field magnetic susceptibility measured at the depth of the mollusk sampling varies between 17.2 and $180.3 \times 10^{-8} \mathrm{~m}^{3} \mathrm{~kg}^{-1}$ (Fig. 3). This fits with the variation described by Kukla for the same stratigraphical inter$\mathrm{val}$, on the same sections, e.g. ranging between 20 and $197 \times 10^{-8} \mathrm{~m}^{3} \mathrm{~kg}^{-1}$ (Kukla et al., 1988; Kukla and An, 1989). Despite small differences at a few levels, the pattern of the variation is identical in the two series of measurements supporting the completeness of our present investigation. This allows, as a first step, to apply the time scale defined by Kukla et al. (1990), and modified by Shackleton et al. (1995) to the sampled section of the Pleistocene.

The fossiliferous layers yielded a total of 141855 individuals in 350 samples. They were mostly present in the loess units, characterized by low MS values, and in the moderately leached paleosols. The horizons showing a strong pedogenesis (high values of MS) did not yield any shell remains due to dissolution. Strong carbonate nodules, occurring at the base of every soil complex, indicate recalcification of the dissolved carbonate. In general, snail preservation is very good in the loess levels, but it is nearly absent in the bottom soils. However, Fig. 3 shows that this is not always the case. The L5 to L4 intervals show the highest counts observed in the sequence and include almost all identified species, whatever their ecological significance, i.e. Vallonia tenera, and Pupilla aeoli, requiring xeric conditions, and Gastrocopta armigerella, preferring moist environments (Fig. 3). The difference between the L5-L4 interval and the rest of the sequence is notable given the large number of individuals, which indicate varied environmental conditions favorable to the development of the mollusk populations. This difference in individuals is also noticeable when gathering the identified species according to their ecological requirement (Rousseau and Wu, 1997; Wu et al., 1996): 


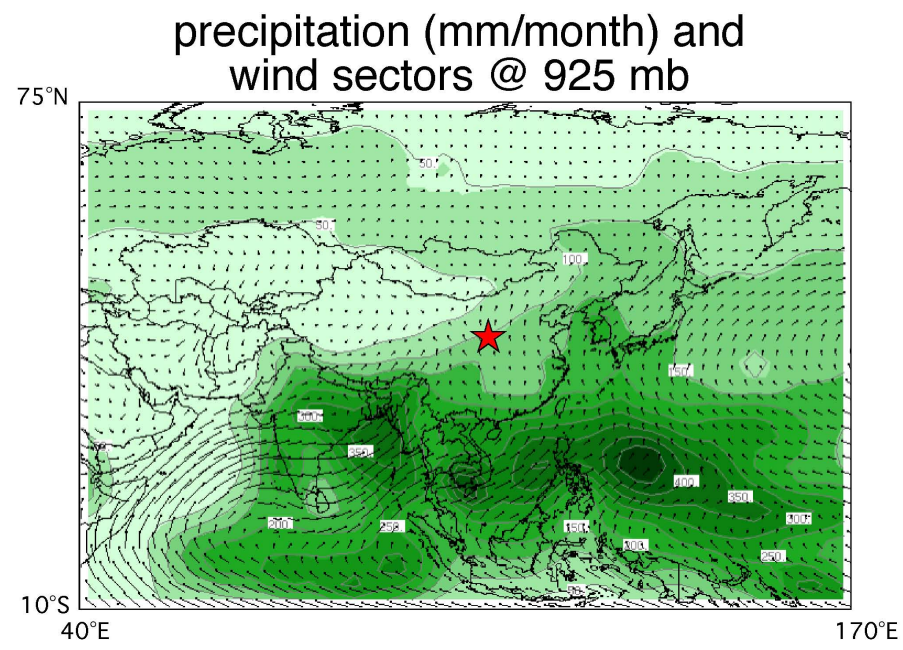

\section{Temperature}

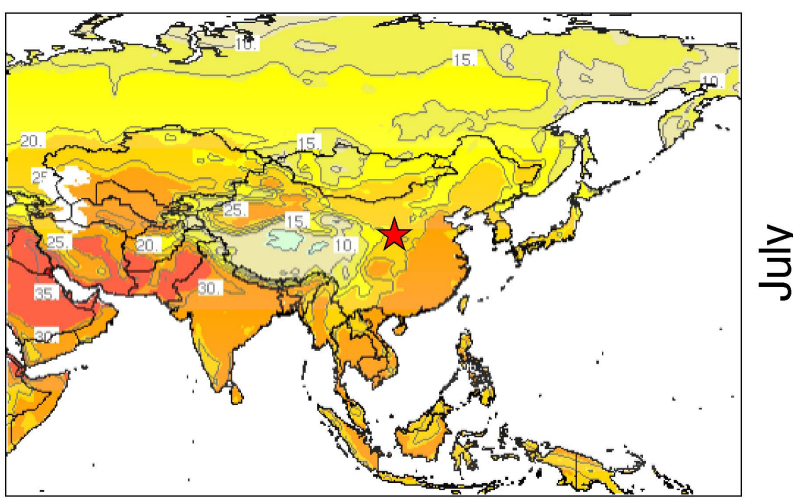

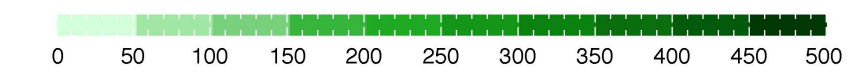
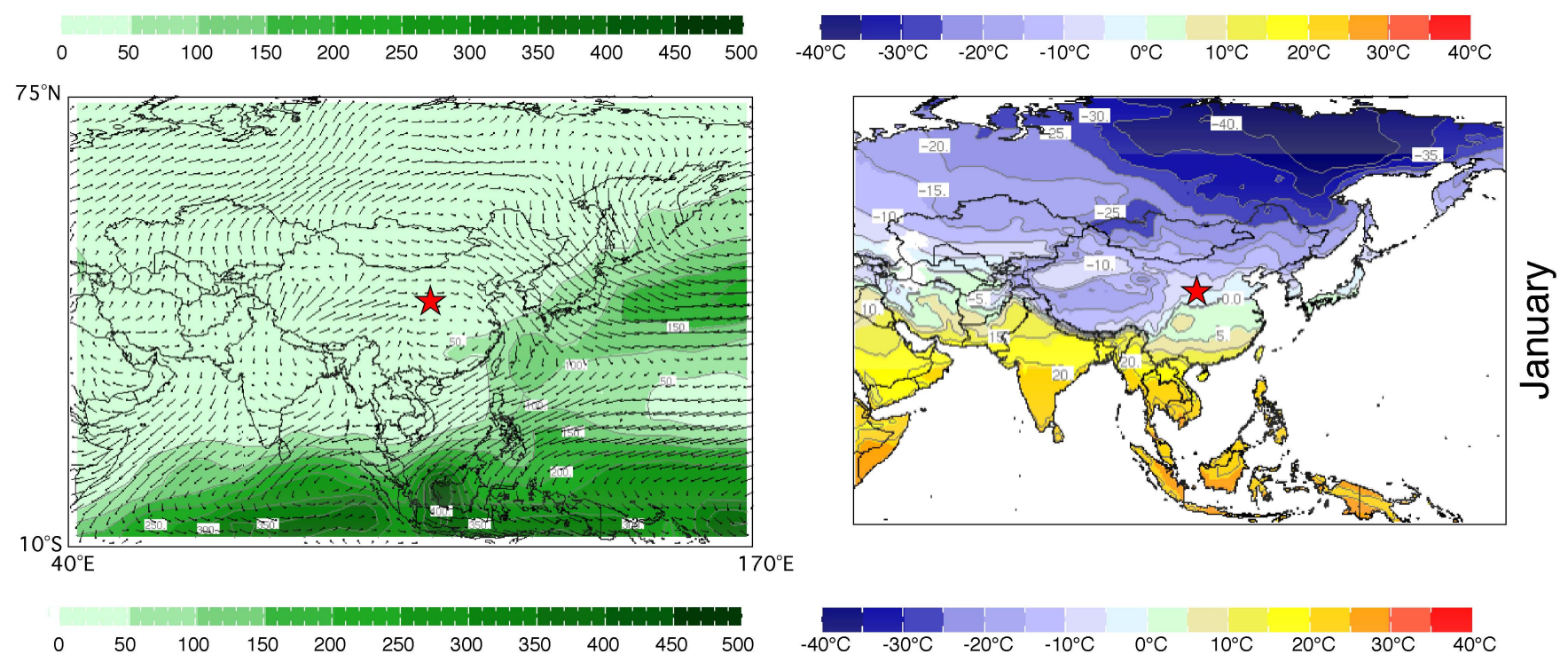

Fig. 2. Distribution of the mean monthly temperature in ${ }^{\circ} \mathrm{C}$ (right), and precipitation in $\mathrm{mm}$ and field wind sectors at $925 \mathrm{mb}$ (left) for July and January. Location of the Luochuan (red star) studied sequence in Central China $\left(35^{\circ} 45^{\prime} \mathrm{N}, 109^{\circ} 25^{\prime} \mathrm{E}\right.$ on the Loess Plateau) at the modern northern limit of the East-Asian summer monsoon (data from http://iridl.ldeo.columbia.edu/).

(1) The cold-aridiphilous taxa, Vallonia tenera, Pupilla aeoli, Cathaica richtofeni, C. pulveratrix, and C. pulveraticula, are species living in dry places, exposed to the sun. While the modern distribution of $V$. tenera and $P$. aeoli is restricted to the NW continental interior, not reached by summer monsoon, the former lives in dry environments with a mean annual precipitation of about 200 to $350 \mathrm{~mm}$ while the latter prefers a wider range of conditions (Mean annual temperature (MAT) of about 5.8 to $10.5^{\circ} \mathrm{C}$ and Mean annual precipitation (MAP) of about 200 to $500 \mathrm{~mm}$ ) (Wu et al., 2001). These species are interpreted as characterizing the so-called Asian winter monsoon.

(2) The hygrophilous, warmth and moisture loving taxa are interpreted as characterizing the East-Asian summer monsoon. This group includes Macrochlamys angi- gyra, Opeas striatissimum, Vitrea pygmaea, Gastrocopta armigerella, Punctum orphanum, Metodontia yantaiensis, M. huaiensis, M. beresowski, Kaliella lamprocystis and Succinea sp.

(3) A third group can be formed from the previous one consisting of the species of Macrochlamys, Opeas, Vitrea, Gastrocopta and Punctum, which live in particularly warm and wet habitats, currently distributed in southeastern China (Chen et al., 1985; Chen and Gao, 1987; Yen, 1939). Their fossil occurrence in the studied section is an indicator of humid conditions associated with particularly strong summer monsoons. Their occurrence in the Luochuan loess sequence, especially within loess units, characterizes intervals during which a persistent but weak summer monsoon, could reach central China during glacial times. 


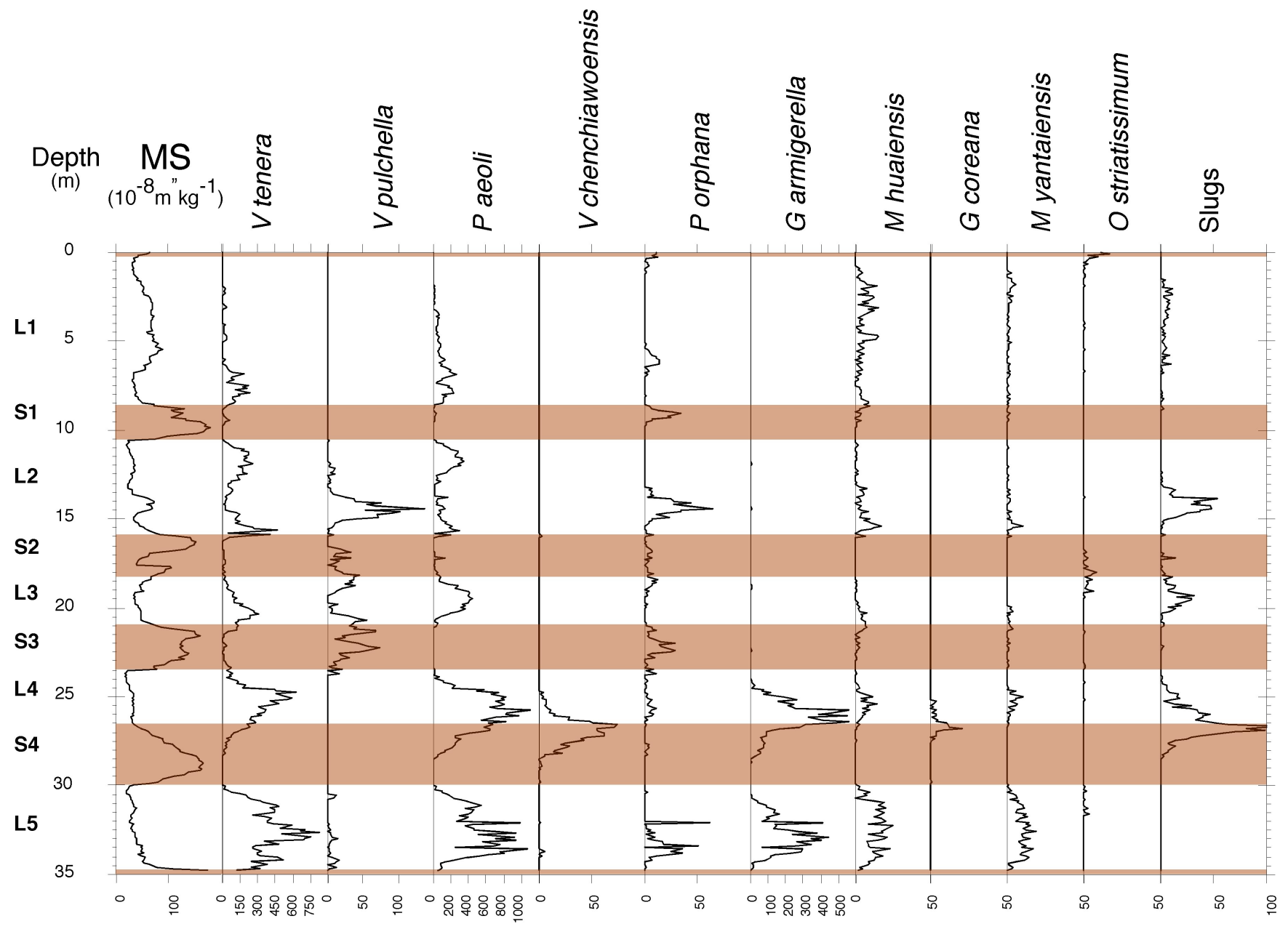

Fig. 3. Composite record of the variation of the low field magnetic susceptibility (MS) and of the individual counts in the identified species downward the stratigraphy of the Luochuan loess sequence in Potou. S0-S4 corresponds to the identified paleosol complexes, characterized by the brown boxes, L1-L5 to the glacial loess units. The low field magnetic susceptibility was measured in the field using a Bartington portable MS2 susceptibility meter and performing 10 readings. The total count of individuals in every sample was extracted from about $15 \mathrm{kgs}$ of sediment.

The thermophilous-moist species are presently living in southern China and for those, labeled "orientals" in the very south of China under particularly warm and moist conditions. Therefore assuming that they did not change their ecological characteristics, they cannot survive under dry and cold conditions, even during their period of activity, because they simply are not adapted to such environments. Indeed the ecological niches yielded by moist and warm conditions are much more diverse and offer numerous possibilities to terrestrial mollusk to develop. Under cold and arid conditions, the environmental niches are much more reduced in number, and only persist species adapted to such drastic conditions. This is classical to observe in Northern Hemisphere, a northward reduction in the number of species, whatever the group concerned, and a high specialization of the species to frost. So, even if drastic conditions prevailed during glacial times, there remained suitable conditions for snail growth probably during mid-Spring. However these identified cold aridiphilous species have a northern modern distribution, and identifying them in our southern sequences implies a shift of northern conditions southward, yielding thus more continental environments.

The thermophilous-moist species group indicates that phases of the summer monsoon occurred during the different climatic cycles, perhaps even during peak glacial intervals. There, the summer monsoon strength is obviously low compared to the winter monsoon, which remains dominant and marked by the cold-aridiphilous species group. These short events have been previously correlated during the last climatic cycle with summer monsoon proxies deduced from modeling and pedogenic studies (Rousseau and Wu, 1997). However these short events do not have the same magnitude as those observed during L5, L4 and L2 loess units. During the three last cycles, a phase of strong summer monsoon 


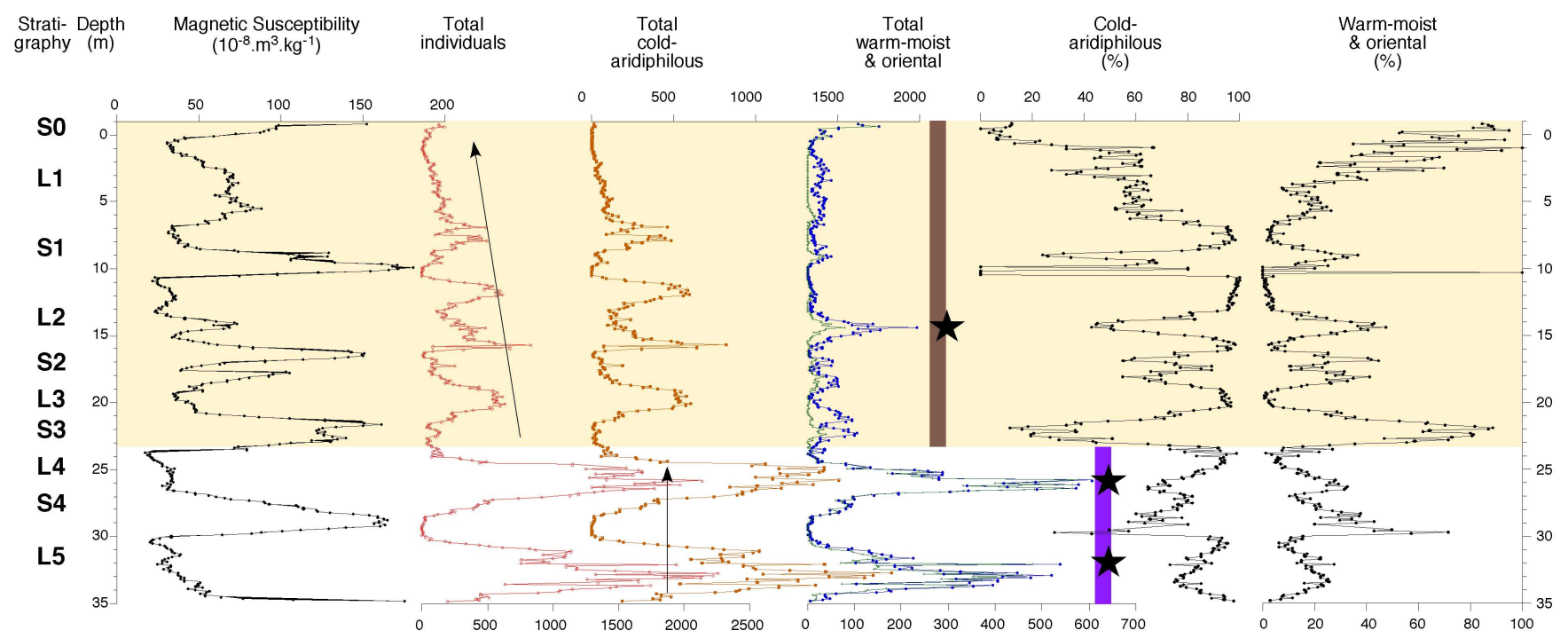

Fig. 4. Characterization of the three exceptionally strong summer monsoons during glacial conditions in the last $470 \mathrm{kyr}$. Variation in counts and percentages versus depth of the main groups (warm-moist and oriental individuals are respectively in in blue and green) and comparison with low field magnetic susceptibility (MS). MS is used to identify the main stratigraphical unit and is a general climate indicator (Kukla and An, 1989). The light yellow box characterizes the last three climatic cycles (Sn-Ln), n being the label of the cycle from the top with 0 for the present one represented by the Holocene interglacial, during which relative low values are found for the total count of individuals and also in the different ecological groups. The two first cycles (L5 and S4-L4) indicate much higher counts in all the discussed categories. The stars mark the three exceptional summer monsoon events identified in the studied sequence, in the last $470 \mathrm{kyr}$. The coldaridiphilous species consist of Vallonia tenera, Pupilla aeoli, Cathaica richtofeni, C. pulveratrix, and C. pulveraticula. The hygrophilous set includes Macrochlamys angigyra, Opeas striatissimum, Vitrea pygmaea, Gastrocopta armigerella, Punctum orphanum, Metodontia yantaiensis, M. huaiensis, M. beresowski, Kaliella lamprocystis and Succinea sp. The third group comprises the species belonging to Macrochlamys, Opeas, Vitrea, Gastrocopta and Punctum.

is identified during glacial L2 (Rousseau and Wu, 1999) (Fig. 4). It is marked by a higher number of thermophilousmoist individuals associated with high counts of the oriental species. Conversely, L4-S4 and L5 units show a much different pattern than the youngest ones. Both thermophilousmoist and cold-aridiphilous groups show higher individuals counts, which should correspond to different environmental and climatic conditions. Furthermore, the thermophilous group shows high values during L4 and L5 glacials, a pattern similar to that observed in L2 stratigraphical unit (Fig. 4).

\section{Discussion}

\subsection{Monsoon evidence}

The extended record presented in this paper shows variations, which are similar to the already observed pattern in the three last climatic cycles (Wu et al., 2001). The authors had linked variations in the occurrence of two cold species, Vallonia tenera and Pupilla muscorum, with eccentricity and obliquity whereas the moist-demanding species, Punctum orphana, showed fluctuations associated with obliquity and precession.
Although the main period of the physiological activity of terrestrial mollusks takes place between mid-Spring and mid-Autumn, the species have varying reactions to cold temperatures through a more or less determined tolerance (eury- or stenothermal). If the temperature gets too cold in winter, heart, respiratory and excretory rhythms are considerably reduced, the body retracts into the shell and is preserved from outside by the epiphragm, the shells lying under various available shelters or buried in the near-surface ground (Solem, 1984). However, passed a precise threshold varying from one species to another, cells can freeze leading to death and the decimation of the population (Riddle, 1983). Contrarily, if the local temperature and moisture conditions remain acceptable for the observed species, the individuals renew their physiological activity the following spring, and thus can breed and develop (Cook, 2001; Schmidt-Nielsen et al., 1971). In the studied area, the moist-thermophilous species have lower tolerance to cold temperatures than their cold-aridiphilous counterparts. These species prefer mild conditions and some of them prefer subtropical conditions.

Interestingly, both warm-moist and cold-arid demanding taxa, hereafter referenced as summer and winter monsoon indices (respectively SMI and WMI), are preserved in much greater numbers in the older (L5-L4) cycles than in the younger ones. However, after carefully cleaning the sections 


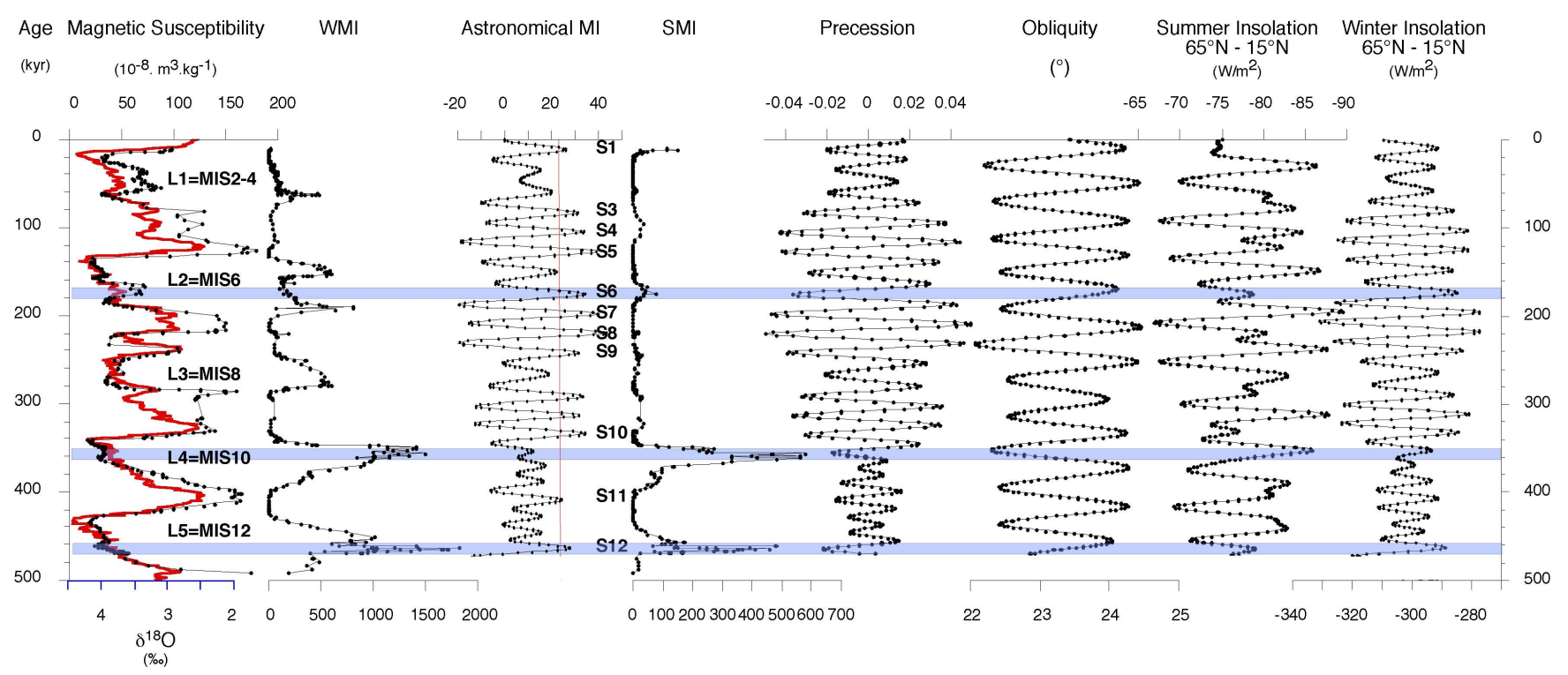

Fig. 5. Time series of the mollusk monsoon indices in Luochuan compared with global proxies. From left to right, Low field magnetic susceptibility, in black, and stacked $\delta^{18} \mathrm{O}$ variations, in red, from Lisiecki and Raymo (Lisiecki and Raymo, 2005). Winter (WMI) monsoon indice, astronomical monsoon index as defined by Rossignol-Strick $(1998,1999)$, the vertical bar characterizing the minimum suggested for a sapropel deposition and summer (SMI) monsoon indice (see suppl. data http://www.clim-past.net/5/157/2009/cp-5-157-2009-supplement. pdf). Computed climatic precession and obliquity (Laskar et al., 2004), the differences in the mean summer and winter insolation at $65^{\circ} \mathrm{N}$ and $15^{\circ} \mathrm{N}$, representing the insolation gradient between the high latitudes and the tropics, calculated with AnalySeries application (Paillard et al., 1996). The gray bands characterize the exceptional glacial summer monsoon intervals. L1 to L5, loess units; S1 to S12: Mediterranean sapropels, MIS 2 to MIS 12: marine isotope stages.

prior to sampling, one did not notice any signs of exceptional taphonomical processes, inducing a particular transport, which could explain differences in individual counts. While strong pedogenesis, inducing leaching of the sediment and thus the dissolution of the embedded shells, was observed for the peak interglacial intervals leading to the occurrence of massive carbonate concretions at the base of the paleosols, no preservation discrepancy has been observed in the remaining units of the studied sequence. The Xifeng loess sequence, some $150 \mathrm{~km}$ westward from Luochuan, shows similar high counts of the same species, and even higher numbers than in Luochuan, thus supporting our interpretation (Wu et al., 2007). These ecological variations then cannot be related to local variations but must be related to particular environmental and climatic conditions, expressed by the occurrence of particular warm-moist species during glacial intervals during which shell dissolution is expected to be absent.

\subsection{Timing of these events: new chronology of the studied section}

Interpreting the timing in the abundance variation in the different ecological groups of species requires use of an accurate time scale. In previous investigations, we applied the chronology developed by Kukla et al. (1990) using the low field magnetic susceptibility signal. However, despite refinements by Shackleton et al. (1995), this time scale leads to some discrepancies between the terrestrial signal and the general climate variations as defined by different global proxies such as deuterium measured in the the Antarctic icecore. (EPICA, 2004) or the $\delta^{18} \mathrm{O}$ marine stack of the last $5 \mathrm{Myr}$ (Lisiecki and Raymo, 2005). The linear correlation between the Chinese loess chronology based on the susceptibility and the corresponding time scale from the Antarctica Dome C ice-core is for example, 0.13 . The susceptibility chronology assumes a constant deposition rate of magnetic grains between magnetic reversals (Kukla et al., 1988). This hypothesis has been demonstrated to be partly correct especially in the soil complexes because of the in situ biological formation of magnetic grains (Zhou et al., 1990). We refined the loess time scale (Fig. 5) by tuning the magnetic susceptibility record to the stacked record of marine benthic $\delta^{18} \mathrm{O}$ (Lisiecki and Raymo, 2005).

\subsection{The "glacial" EA summer monsoon events}

We demonstrated in previous papers, (Rousseau and $\mathrm{Wu}$, 1997, 1999; Wu et al., 2001, 2007), that glacial times, i.e. MIS $2-4,6,8$, and 10 recorded intervals during which a summer monsoon signal was preserved in the mollusk record. Moreover we showed for the last climatic cycle that these intervals were fitting with other independent records (pollen, iron content, marine proxy) available in the literature. However the intensity of the signal that we are 
discussing in our present paper is by far much more important, as noticeable on Fig. 5, and in some way exceptional, and because of an on-going project we are not yet able to transform our variations in term of amount of precipitation.

The high values of the summer monsoon index (SMI) within loess unit L2 at about $175 \mathrm{kyr}$, indicates a strong EA summer monsoon during marine isotope stage 6. This event has been previously correlated to particular climatic conditions observed worldwide in other proxies (Clemens et al., 1991; Rossignol-Strick, 1983). It was linked to a strengthened summer monsoon regime over Asia and eastern Africa, implying strong runoff through the Nile contributing to the occurrence of thick sapropel (S6) in the Mediterranean (Rousseau, 2001). Modeling experiments indicated stronger summer insolation conditions than present day at low latitudes, allowing a strong summer monsoon to develop in both Asia and Africa (Masson et al., 2000).

However, our present record indicates that the magnitude of this event is apparently much less pronounced than that observed within older loess units L5 and L4 or that at least the environmental conditions were considerably different.

Contrary to the loess L2 record, both WMI and SMI (winter and summer monsoon indices) show higher values, but not synchronously, during glacial intervals L5 and L4 (Figs. 4, 5). This indicates that the environmental conditions, which induced the development of the moist demanding species, also prevailed for the cold-aridiphilous ones. The observation during L5 (MIS 12) and L4 (MIS 10) is not limited to the Luochuan sequence as it was also observed in the Xifeng loess sequence, located in the southern-central part of the Chinese Loess Plateau, about $150 \mathrm{~km}$ westward of Luochuan (Wu et al., 2007). The high values of both indices during the two L5 and L4 loess units seem to indicate a different seasonal variability than implied for the more recent cycles where the warm species were considerably reduced or almost absent (Rousseau and Wu, 1997, 1999; Wu et al., 2001).

The large development of these warm sensitive species is also associated with reduced winter monsoon flows characterized by low values of the difference between reconstructed mean winter insolation at high and mid latitudes or the gradient between high latitudes and the tropics (Fig. 5). This provided enough favorable environmental conditions to prevent the mollusk populations from collapse. SMI maximums correspond with precession minimums (Fig. 5) throughout the record, even during glacial intervals. Previous interpretations from other proxies were limited to the interglacial periods (An et al., 1991; Heller et al., 1991; Kukla et al., 1988; Kukla and An, 1989). WMI shows high values during glacial intervals in agreement with the classical interpretation of the winter monsoon.

Variations of the orbital parameters during the last $470 \mathrm{kyr}$ provide complementary information for understanding the main variations in Luochuan of the two monsoon indices. Different configurations of the Earth's orbital parameters
(Berger, 1979, 1992) produce variations in insolation which should affect environmental conditions. The high values of SMI during L5 and L4 glacials, at about 470 and $360 \mathrm{kyr}$ respectively, characterize conditions of exceptional summer monsoon during glacials, which corresponds to low precession, northern summer occurring at perihelion, low obliquity, leading to an increased insolation gradient between low and high latitudes (Laskar et al., 2004). The differences of reconstructed mean summer insolation between $15^{\circ}$ and $65^{\circ} \mathrm{N}$, characterize the gradient between the tropics and high latitudes. The mean summer insolation refers to the total insolation over the astronomical summer season (i.e. defined according to the astronomical calendar) divided by the length of the summer season, which varies through time. The gradient is the highest during L5 and L4 events compared to the younger glacial intervals corresponding to marine isotope stages $8,6,4$ and 2 . This implies a potentially strong meridional heat transport, and possibly excess precipitation over the continent (Fig. 5). Conversely, the same differences of insolation during L2 monsoon event, at about $170 \mathrm{kyr}$, are much less important as obliquity is higher. This may partly explain the lower values of SMI in L2 compare to L4 and L5 in glacial intervals.

Based on the magnetic susceptibility and the mean grain size of quartz grains in the Lingtai and Zhaojiachuan sequences, about $150 \mathrm{~km}$ west of Luochuan, Sun et al. (2006) determined the evolution of both summer and winter monsoons over the past 3.6 Myr from the Chinese Loess Plateau. For the winter monsoon, the grain size variation shows the expected classical pattern involving strength in the NW wind regime in winter, which could also be interpreted as a record of atmospheric circulation reorganization. The timing of the exceptional summer monsoon events identified in Luochuan, corresponds to the marked decrease in the grain size in the Lingtai and Zhaojiachuan sequences. These variations are linked to reduced wind dynamics due to the probable reduced pressure gradient between the ocean and the continent. Interestingly, the magnetic susceptibility measured in these northern sequences does not show any record of these events, as also noted in Luochuan. A recently published grain-size study from Xifeng sequence (Guo et al., 2009) shows intervals with particular weak winter monsoon during MIS 6 and 12 about synchronous to the mollusk record. These independent records support that the monsoon variations observed from Luochuan mollusks are not local or regional, but have a more general significance. This interpretation is supported by another independent analysis away from the study area. Further north of the Chinese Loess Plateau, Lake Baikal shows a high accumulation of biogenic silica related to a high level of diatom production between 0.36 and $0.58 \mathrm{Ma}$, especially littoral benthic assemblages. Their composition is unchanged during this interval and is interpreted as suggesting that glacial impacts during this particular interval, were not as extreme as in other Pleistocene glacials (Prokopenko et al., 2002). 
Masson et al. (2000) suggested that the "Indian and African monsoons at $175 \mathrm{ka}$ ", one of the three events we describe, "were stronger than nowadays...", and that high insolation, from this modeling experiment, could explain such strong summer monsoon signal. This is an interesting support to our observation and remains a modeling result totally independent of our study. The Sanbao cave located far inland at $110^{\circ} 26^{\prime} \mathrm{E}$ and $31^{\circ} 40^{\prime} \mathrm{N}$, at the southern edge of the Chinese Loess Plateau, yielded several speleothems which provided a complete record of the past 224000 years (Wang et al., 2008) and represent a particularly reliable reference to compare with (Fig. 1). The $\delta^{18} \mathrm{O}$ variations recorded have been interpreted as indicative of the strength of the East Asian monsoon during the two last climatic cycles. The authors described strong summer monsoon events interpreted as "Chinese interstadials". Concerning our present record, one can quote Wang et al. (2008) who indicate that "the monsoon peaks corresponding to marine isotope stages (MIS) 5.5 and 7.3 are relatively low, and the peak at MIS 6.5 is relatively high". Indeed when comparing these variations, one can notice that the $\delta^{18} \mathrm{O}$ for MIS 6.5 dated at about $175 \mathrm{ka}$, is higher than during interglacials 5.5 and 7.3 , but also is a composite one with 3 identified events thanks to the very high resolution of the record. Thus this independently supports the conclusions of the modeling experiment by Masson et al. (2000) that we were quoting, but also our results. Once more the cave is located at the southern edge of the Chinese Loess Plateau. Now considering what we observe during MIS 6 compare to MIS10 and 12 in Luochuan, taking into account these two different and independent data, we can still remain with "exceptional events". However the magnitude of the variations observed, also noticed in another loess sequence (Wu et al., 2007), requires particular conditions that we cannot explain without considering the particular configuration of the Earth orbit parameters. Observing such development of moisture sensitive individuals required the northward move of the upper boundary of the East Asian summer monsoon as already observed in MIS 6.5 but still with a configuration allowing these particular developments of populations. Indeed the three events correspond to periods of low eccentricity, especially the two oldest that occurred during periods of the lowest eccentricity values of the past 500000 years, which reduces the seasonal change anomalies perpetuating favorable conditions for the moist sensitive mollusks.

\subsection{Global "glacial" summer monsoon events}

A modeling experiment (Masson et al., 2000) supports the characterization of the summer monsoon during marine isotope stage 6 at about $170 \mathrm{ka}$ by terrestrial mollusks. The iron weathering index and the magnetic susceptibility measurements both assumed to be summer monsoon indices, do not indicate significant variation during L2. This also holds for the newly described L5 and L4 intense monsoon signal, at about 470 and $360 \mathrm{kyr}$, respectively. However, investigating paleomonsoon indices in other sub-branches of the monsoon system may shed some light on these results.

The L2 summer monsoon event has already been linked to the East African monsoon by Nile discharges into the Mediterranean contributing to the development of sapropel S6. Similarly, the timing of the L5 summer monsoon event corresponds to sapropel S12 identified by Rossignol-Strick et al. $(1998,1999)$ in the eastern Mediterranean. These sapropels have been interpreted as a response of the climate system to a particular orbital configuration depicted by an astronomical monsoon index, which characterizes the heat budget between the Equator and the Tropics (Rossignol-Strick, 1983). Exceptional monsoon events L5 and L2 correspond to high values of this index. Conversely, the L4 event does not correlate with the maximum of this monsoon index despite corresponding to summer equinox at perihelion. However, the obliquity values are among the lowest of the studied interval, implying a strong heat gradient between upper and lower latitudes in the Northern Hemisphere possibly contributing to heat transport northward and increased precipitation over Chinese Loess Plateau. Rossignol-Strick et al. (1998) showed that during the last $250 \mathrm{kyr}$, sapropels were deposited only when summer insolation at low latitudes reached its highest peaks. This stable pattern did not prevail during the $1 \mathrm{Myr}-250 \mathrm{kyr}$ interval, although some earlier sapropels were deposited during intervals of low monsoon index values. However, one should note the chronological problem of sapropels S10 and S11 which seem to be difficult to date (Rossignol-Strick, 1983; Rossignol-Strick et al., 1998, 1999). S11 could be possibly allocated to summer monsoon event L4 (Rossignol-Strick, 1983).

As mentioned previously, the Asian monsoon consists of the Indian and EA monsoons. In the Indian Ocean, Clemens et al. (1991) indicate a strong contrast in the sea surface temperature over this area inducing a severe summer monsoon at about $176 \mathrm{ka}$. Indian Ocean core MD900963 retrieved next to the Maldives islands has a planktonic $\delta^{18} \mathrm{O}$ record showing precession related variations that Bassinot et al. (1994) interpreted as characteristic of local salinity fluctuations superimposed on the global ice volume signal. The observed oscillations of the sea water salinity could be linked with summer monsoon activity. Bassinot et al. (1994) demonstrated that these precessional changes in $\delta^{18} \mathrm{O}$ are in agreement with oscillations predicted by the orbital theory of climate. Interestingly some of these changes also correspond to our exceptional events of the summer monsoon within the errors due to the definition of the respective time series.

\subsection{A possible mechanism for the occurrence of the exceptional strong summer monsoon during glacial intervals}

The monsoon system is much more complex than indicated above, and includes 6 subsystems which are related 
(Trenberth et al., 2000, 2006). The EA monsoon itself can be subdivided into the Western North Pacific and EA sensu lato, according to the latitude considered. Trenberth et al. (2006) studying the global perspectives of the Asian monsoon, concluded, after investigating both interannual and interdecadal variations, that the "global system does not vary coherently, but rather the regional monsoons and ENSO are in competition with one another". Wang et al. (2003) analyzed the contrast between the Indian and EA regions through time, showing differences in interannual variations between these two main regions, related to internal factors in the system such as El Niño/La Niña interactions. However, they indicated that such factors could differ at geologic/orbital timescales. Wang et al. (2003) concluded alternatively that "large changes in the Pacific thermal conditions, such as the disappearance of El Niño, may significantly alter the intensity of the EA monsoon, but not the Indian monsoon". Complementary to this study, Goes et al. (2005) analyzed the relationship between the recent declining winter and spring snow cover over Eurasia and stronger summer monsoon winds over western Arabian Sea. Indeed this study reports the pronounced decline of snow cover over Northern Eurasia poleward of $70^{\circ} \mathrm{N}$. Reporting for different regions, they mention observations in Northeast Russia over Southwest Asia and over northern Indian Himalaya Tibetan Plateau region. Such decline in snow cover creates dynamical conditions inducing stronger winds and lower SSTs across the Arabian Sea. Such interesting mechanism appears particularly important to consider but cannot be assumed from our snail record. Thus only modeling experiments would allow to testing such hypothesis for our concerned glacial intervals. Yin et al. (2008) recently demonstrated in a modeling experiment of MIS 13, that a strong EA summer monsoon in the past could be related to planetary waves linked to the occurrence, size, and position of the Northern Hemisphere ice sheets, influencing the precipitation band over East Asia at the latitude of the Chinese Loess Plateau. Could the past variability of ENSO be a possible factor by itself or considering the results of Yin et al. (2008), a complementary factor allowing a more accurate interpretation of the exceptional monsoon signals as recorded in the studied loess sequences? Investigating the possible origin of the abrupt climate changes in the tropics, Clement et al. (2001) demonstrated that the variability of the atmospheric circulation linked to ENSO can lock for several centuries under particular orbital configurations affecting the sea surface temperature and leading to possible shutdowns of ENSO. They also indicated that the maximum length of ENSO shutdowns occurred at times of low eccentricity. Thus, over the past $500 \mathrm{kyr}$, the time of maximum ENSO shutdowns mainly concentrated over the interval 450$350 \mathrm{kyr}$, which also corresponds to the time interval of the first two exceptional summer monsoons observed in Chinese loess sequences. Clement et al. (2001) also mention a possible occurrence of an ENSO shutdown between 200 and $150 \mathrm{kyr}$ but much weaker than in the previous interval.
The combination of the observed mechanisms in the present regions deduced from the observed coupled monsoon system (Webster, 2006) with the modeling experiment initiated to link abrupt changes with variations in the tropical Pacific and the strong summer monsoon in MIS 13, may help explain the occurrence of these exceptional summer monsoons events during glacial intervals. However, a proper modeling experiment designed for the considered intervals is needed to support our interpretation.

Beside the probable contribution of these climate mechanisms, it is striking that at least the L2 and L5 monsoon events are coeval with tectonic events identified in Asia. $\mathrm{Li}$ (1991) investigated the terraces of the Yellow River in the Lanzhou region, northwest of the Chinese Loess Plateau, as a benchmark of the environmental effects of the uplift of the Tibetan plateau. Although this interpretation of the terraces is still under debate, it is interesting to notice that he identified six terraces labeled $\mathrm{T} 1$ to $\mathrm{T} 6$ respectively and dated them to about $0.015,0.05,0.15,0.6,1.20$ and $1.48 \mathrm{Ma}$, respectively. A severe incision of the T3 terrace occurred during the deposition of loess unit L2 on the Loess Plateau, while the previous T4 incision occurred with the L5 deposition. Furthermore, the T4 down cutting, appears much more important than in $\mathrm{T} 3$ corresponding to a possibly more intense tectonic uplift $(\mathrm{Li}, 1991)$. Then this apparent synchronism of the tectonic events in the Tibetan plateau with the exceptional monsoon events is worth noting despite possible dating errors, as indicated by the modeling experiment of Yin et al. (2008). This study underlines the feedback provided by the Tibetan Plateau uplift and Northern Hemisphere ice sheets extent on the strength of EA summer monsoon. Were the uplift events driving climatic changes by modifying the atmospheric circulation as inferred by the authors? Whether these tectonic events are related to the monsoon is unknown but the apparent synchronism is worth pursuing in further studies.

\section{Conclusions}

Three exceptional summer monsoon events have been indicated from the study of the terrestrial mollusks in the Luochuan sequence, located in the southern-central Chinese Loess Plateau. These events are not strickly local as counterparts exist in other records from the Loess Plateau and also further North in Lake Baikal.

The L5 and L2 exceptional EA summer monsoon events, at $470 \mathrm{ka}$ and $170 \mathrm{ka}$ respectively, appear to have a global distribution as equivalents were identified in the East African and Indian summer monsoon record via the occurrence of eastern Mediterranean sapropels and $\delta^{18} \mathrm{O}$ variations in the Indian Ocean. They correspond to increased precipitation over the continents, which responds to a specific orbital configuration implying a strong intertropical gradient expressed by the monsoon index. Conversely, the L4 summer 
monsoon Asian event, despite a weak intertropical gradient (low monsoon index), corresponds to low obliquity, as for L5 event, inducing strong continental gradient between low and high latitudes. However, the astronomical configuration could not have been the only driver of these exceptional changes involving also a reorganization of both marine, via ENSO, and atmospheric circulations, via temperature gradients between upper and lower latitudes, tectonic and the extent of Northern Hemisphere ice-sheets. Investigating other records to seek these particular events, and performing modeling experiments as already done for the L2 event $170 \mathrm{kyr}$ would then be crucial to analyze in detail these particular climate patterns.

Acknowledgements. This study is supported by the French CNRS, through the CNRS-CAS scientific exchange program and the Chinese NSF through grant 40672116. We thank, Joyce Gavin, André Berger, George Kukla, Gerald Ganssen and Eric Wolff, Marie-France Loutre, Zhengtang Guo and an anonymous reviewer for comments and suggestions that benefited the manuscript. Joyce Gavin considerably improved the English, and Marie-France Loutre did a great job in editing this paper. Preparation of this manuscript started during the stay of the first author at University of Bayreuth thanks to a research award from the Alexander von Humboldt foundation. We would like to thank the numerous students, post-docs and farmers who helped us during field work in the preparation of the sampled sections in Luochuan, collecting and sieving the sediment samples in Potou. The first author wants to thank the organizing committee of the Louvain-la-Neuve 2008 symposium for inviting him to present his results during this meeting. Last but not the least, this Chinese-French collaboration could not have been possible without the help and strong support from Professor Liu Tungsheng that the authors want to sincerely thank and will never forget. This is LDEO contribution 7254 .

Edited by: M.-F. Loutre

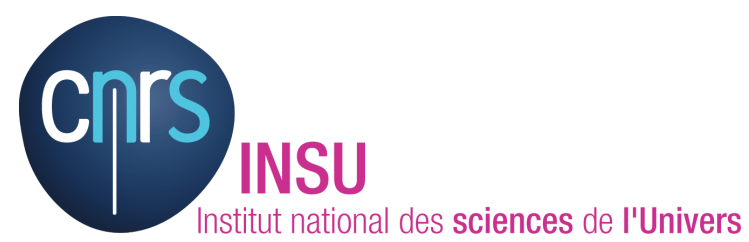

The publication of this article is financed by CNRS-INSU.

\section{References}

An, Z.: The history and variability of the East Asian paleomonsoon climate, Quaternary Sci. Rev., 19, 171-187, 2000.

An, Z. S., Kukla, G., Porter, S. C., and Xiao, J. L.: Magnetic susceptibility evidence of monsoon variation on the loess plateau of Central China during the last 130000 years, Quaternary Res., 36, 29-36, 1991.

Bassinot, F. C., Labeyrie, L. D., Vincent, E., Quidelleur, X., Shackleton, N. J., and Lancelot, Y.: The astronomical theory of climate and the age of the Brunhes-Matuyama magnetic reversal, Earth Planet. Sc. Lett., 126, 91-108, 1994.

Berger, A. L.: Long term variations of daily insolation and Quaternary climatic changes., Am. Meteorol. Soc., 35, 2362-2367, 1979.

Berger, A. L.: Astronomical theory of paleoclimates and the last glacial-interglacial cycle, Quaternary Sci. Rev., 11, 571-581, 1992.

Chen, D., Gao, J., Gao, F., and Liu, T.: Fossil snails and their environment, in: Loess and the environment, edited by: Press, C. O., Beijing, 1-251, 1985.

Chen, D. N. and Gao, J. X.: Terrestria Mollusca, in Chinese ed., Economic Fauna Sinica of China, edited by: Editorial Committee of Fauna Sinica, A. S., Science Press, Beijing, 186 pp., 1987.

Clemens, S., Prell, W., Murray, D., Shimmield, G., and Weedon, G.: Forcing mechanisms of the Indian Ocean monsoon., Nature, 353, 720-725, 1991.

Clemens, S. C.: Dust response to seasonal atmospheric forcing: Proxy evaluation and calibration, Paleoceanography, 13, 471490, 1998.

Clement, A. C., Cane, M. A., and Seager, R.: An orbitally driven tropical source for abrupt climate change, J. Climate, 14, 23692375, 2001.

Cook, A.: Behavioural ecology: On doing the right thing, in the right place, at the right time, in: The biology of terrestrial molluscs, edited by: Barker, G. M., CABI Publisher, Hamilton, New Zealand, 447-487, 2001.

Ding, Z., Rutter, N., and Liu, T.: Pedostratigraphy of Chinese Loess Deposits and Climatic Cycles in the Last 2,5 myr, Catena, 20, 73-91, 1993.

Ding, Z., Liu, T., Rutter, N. W., Yu, Z., Guo, Z., and Zhu, R.: IceVolume Forcing of East Asian Winter Monsoon Variations in the Past 800000 Years, Quaternary Res., 44, 149-159, 1995.

Ding, Z., Sun, J., Rutter, N. W., Rokosh, D., and Liu, T.: Changes in sand content of loess deposits along a North-South transect of the Chinese loess plateau and the implications for desert variations, Quaternary Res., 52, 56-62, 1999a.

Ding, Z. L., Sun, J. M., Liu, T. S., Zhu, R. X., Yang, S. L., and Guo, B.: Wind-blown origin of the Pliocene red clay formation in the central Loess Plateau, China, Earth Planet. Sc. Lett., 161, 135-143, 1998.

Ding, Z. L., Xiong, S. F., Sun, J. M., Yang, S. L., Gux, Z. Y., and Liu, T. S.: Pedostratigraphy and paleomagnetism of a $\sim 7.0 \mathrm{Ma}$ eolian loess-red clay sequence at Lingtai, Loess Plateau, northcentral China and the implications for paleomonsoon evolution, Palaeogeogr., Palaeoclimatol., Palaeoecol., 152, 1999 b.

Ding, Z. L., Derbyshire, E., Yang, S. L., Yu, Z. W., Xiong, S. F., and Liu, T. S.: Stacked 2.6-Ma grain size record from the Chinese loess based on five sections and correlation with the deep-sea $\delta^{18} \mathrm{O}$ record, Paleoceanography, 17, 5.1-5.21, 2002.

EPICA, community members: Eight glacial cycles from an Antarctic ice core, Nature, 429, 623-628, 2004.

Goes, J. I., Thoppil, P. G., Gomes, H. D., and Fasullo, J. T.: Warming of the Eurasian landmass is making the Arabian Sea more productive, Science, 308, 545-547, doi:10.1126/science.1106610, 2005.

Guo, Z. T., Biscaye, P., Wei, L., Chen, X., Peng, S., and Liu, T. S.: Summer monsoon variations over the last 1.2 Ma from the weathering of loess-soil sequences in China, Geophys. Res. Lett., 
27, 1751-1754, 2000.

Guo, Z. T., Ruddiman, W. F., Hao, Q. Z., Wu, H. B., Qiao, Y. S., Zhu, R. X., Peng, S. Z., Wei, J. J., Yuan, B. Y., and Liu, T. S.: Onset of Asian desertification by $22 \mathrm{Myr}$ ago inferred from loess deposits in China, Nature, 416, 159-163, 2002.

Guo, Z. T., Berger, A., Yin, Q. Z., and Qin, L.: Strong asymmetry of hemispheric climates during MIS-13 inferred from correlating China loess and Antractica ice records, Clim. Past, 5, 21-31, 2009, http://www.clim-past.net/5/21/2009/.

Hatté, C., Fontugne, M., Rousseau, D. D., Antoine, P., Zoller, L., Tisnerat-Laborde, N., and Bentaleb, I.: $\delta^{13} \mathrm{C}$ variations of loess organic matter as a record of the vegetation response to climatic changes during the Weichselian, Geology, 26, 583-586, 1998.

Hatté, C., Antoine, P., Fontugne, M., Lang, A., Rousseau, D. D., and Zöller, L.: $\delta^{13} \mathrm{C}$ of loess organic matter as a potential proxy for precipitation, Quaternary Res., 55, 33-38, 2001.

Heller, F. and Liu, T. S.: Magnetostratigraphical dating of loess deposits in China, Nature, 300, 1169-1172, 1982.

Heller, F., Liu, X., Liu, T., and Xu, T.: Magnetic susceptibility of loess in China, Earth Planet Sc. Lett., 103, 301-310, 1991.

Johnson, R. H. and Houze, R. A.: Precipating cloud systems of the Asian monsoon, in: Monsoon meteorology, edited by: Chang, C. P., and Krishnamurti, N., Oxford Monographs on Geology and Geophysics, Oxford University Press, New York, 298-353, 1987.

Kukla, G., Heller, F., Liu, X. M., Xu, T. C., Liu, T. S., and An, Z. S.: Pleistocene climates in China dated by magnetic susceptibility., Geology, 16, 811-814, 1988.

Kukla, G. and An, Z. S.: Loess stratigraphy in central China., Palaeogeogr., Palaeoclimatol., Palaeoecol., 72, 203-225, 1989.

Kukla, G., An, Z. S., Melice, J. L., Gavin, J., and Xiao, J. L.: Magnetic susceptibility record of Chinese Loess, Transactions of the Royal Society Edinburgh, Earth Sci., 81, 263-288, 1990.

Laskar, J, Robutel, P., Joutel, F., Gastineau, M., Correia, A. C. M., and Levrard, B.: A long-term numerical solution for the insolation quantities of the Earth, Astronom. Astrophys., 428, 261285, doi:10.151/0004-6361-20041335, 2004.

Li, F. J., Wu, N. Q., Pei, Y. P., Hao, Q. Z., and Rousseau, D. D.: Wind-blown origin of Dongwan late Mio-Pliocene dust sequence documented by land snail record in western Chinese Loess Plateau, Geology, 34, 405-408, 2006.

Li, J.: The environmental effects of the uplift of the Qinghai-Xizang Plateau, Quaternary Sci. Rev., 10, 479-483, 1991.

Lisiecki, L. E. and Raymo, M. E.: A Pliocene-Pleistocene stack of 57 globally distributed benthic delta O-18 records, Paleoceanography, 20, PA1003, doi:1010.1029/2004PA001071, 2005.

Liu, T. S. (ed.).: Loess and the environment, China Ocean Press, Beijing, 251 pp., 1985.

Liu, T. S., Ding, Z. L., and Guo, Z. T.: Loess, environment and Global Change, China Ocean Press, Beijing, 228 pp., 1991

Lozek, V.: Quartärmollusken der Tschechoslowakei, Rozpr. Ustred. ustavu. Geol., ed., Verlag der Tschechoslowakischen Akademie der Wissenschaften, Praha, 374 pp., 1964.

Maher, B. A. and Thompson, R.: Paleoclimatic Significance of the Mineral Magnetic Record of the Chinese Loess and Paleosols, Quaternary Res., 37, 155-170, 1992.

Maher, B. A., and Thompson, R.: Pedogenesis and paleoclimate: Interpretation of the magnetic susceptibility record of Chinese loess-paleosol sequences: Comments and Reply, Geology, 857-
860, 1994.

Maher, B. A.: Magnetic properties of modern soils and Quaternary loessic paleosols: paleoclimatic implications, Palaeogeogr., Palaeoclimatol., Palaeoecol., 137, 25-54, 1998.

Masson, V., Braconnot, P., Cheddadi, R., Jouzel, J., Marchal, O., and de Noblet, N.: Simulation of intense monsoons under glacial conditions, Geophys. Res. Lett., 27, 1747-1750, 2000.

Paillard, D., Labeyrie, L., and Yiou, P.: Macintosh program performs time-series analysis, Eos Trans. AGU, 77, 379, 1996.

Pecsi, M.: Loess is not just the accumulation of dust, Quatern. Int., 7/8, 1-21, 1990.

Porter, S. C. and An, Z. S.: Correlation between climate events in the North Atlantic and China during the last glaciation, Nature, 375, 305-308, 1995.

Prokopenko, A. A., Williams, D. F., Kuzmin, M. I., Karabanov, E. B., Khursevich, G. K., and Peck, J. A.: Muted climate variations in continental Siberia during the mid-Pleistocene epoch, Nature, 418, 65-68, 2002.

Puisségur, J. J.: Mollusques continentaux quaternaires de Bourgogne. Significations stratigraphiques et climatiques. Rapports avec d'autres faunes boréales de France, Mémoires Géologiques de l'Université de Dijon, Centre de paléogéographie et de paléobiologie évolutives, Dijon, 241 pp., 1976.

Puisségur, J. J.: Les mollusques des séries loessiques à Achenheim, Recherches géographiques à Strasbourg, 7, 71-96, 1978.

Rea, D. K., Snoeckx, H., and Joseph, L. H.: Late Cenozoic eolian deposition in the north Pacific: Asian drying, Tibetan uplift, and cooling of the Northern Hemisphere, Paleoceanography, 13, 215-224, 1998.

Riddle, W. A.: Physiological ecology of land snails and slugs, in: The Mollusca: Ecology, edited by: Russell-Hunter, W. D., Academic Press edit, 431-461, 1983.

Rossignol-Strick, M.: African monsoons, an immediate climate response to orbital insolation, Nature, 303, 46-49, 1983.

Rossignol-Strick, M., Paterne, M., Bassinot, F. C., Emeis, K. C., and De Lange, G. J.: An unusual mid-Pleistocene monsoon period over Africa and Asia, Nature, 392, 269-272, 1998.

Rossignol-Strick, M. and Paterne, M.: A synthetic pollen record of the eastern Mediterranean sapropels of the last $1 \mathrm{Ma}$ : Implications for the time-scale and formation of sapropels, Mar. Geol., 153, 221-237, 1999.

Rousseau, D. D.: Réponses des malacofaunes terrestres quaternaires aux contraintes climatiques en Europe septentrionale, Palaeogeogr., Palaeoclimatol., Palaeoecol., 69, 113-124, 1989.

Rousseau, D. D., Puisségur, J. J., and Lautridou, J. P.: Biogeography of the Pleistocene Pleniglacial malacofaunas in Europe. Stratigraphic and climatic implications, Palaeogeogr., Palaeoclimatol., Palaeoecol., 80, 7-23, 1990.

Rousseau, D. D. and Wu, N. Q.: A new molluscan record of the monsoon variability over the past $130000 \mathrm{yr}$ in the Luochuan loess sequence, China, Geology, 25, 275-278, 1997.

Rousseau, D. D. and Wu, N. Q.: Mollusk record of monsoon variability during the L2-S2 cycle in the Luochuan Loess sequence, China, Quaternary Res., 52, 286-292, 1999.

Rousseau, D. D.: Loess biostratigraphy: new advances and approaches in mollusk studies, Earth-Sci. Rev., 54, 157-171, 2001.

Rutter, N., Evans, M. E., and Wang, Y.: Magnetostratigraphy of the Baoji Loess-Paleosol Section in the North-Central China Loess Plateau, Quatern. Int., 7/8, 97-102, 1990. 
Schmidt-Nielsen, K., Taylor, C. R., and Schkolnik, A.: Desert snails: problems of heat, water and food, J. Exp. Biol., 55, 385398, 1971.

Shackleton, N. J., An, Z., Dodonov, A. E., Gavin, J., Kukla, G. J., Ranov, V. A., and Zhou, L. P.: Accumulation rate of loess in Tadjikistan and China: Relationship with global ice volume, Quat. Proc., 4, 1-6, 1995.

Solem, A.: A world model of land snail diversity and abundance, in: World-wide snails. Biogeographical studies on non-marine Mollusca, edited by: Solem, A., and Bruggen, A. C. v., Brill \& Backhuys, Leiden, 6-22, 1984.

Sun, Y. B., Clemens, S. C., An, Z. S., and Yu, Z. W.: Astronomical timescale and palaeoclimatic implication of stacked 3.6-Myr monsoon records from the Chinese Loess Plateau, Quaternary Sci. Rev., 25, 33-48, 2006.

Tao, S. and Chen, L.: A review of recent research on the East Asian summer monsoon in China, in: Monsoon meteorology, edited by: Chang, C. P. and Krishnamurti, N., Oxford Monographs on Geology and Geophysics, Oxford University Press, New York, 60-92, 1987.

Trenberth, K. E., Stepaniak, D. P., and Caron, J. M.: The global monsoon as seen through the divergent atmospheric circulation, J. Climate, 13, 3969-3993, 2000.

Trenberth, K. E., Hurrell, J. W., and Stepaniak, D. P.: The Asian monsoon: Global perspectives, in: The Asian Monsoon, edited by: Wang, B., Springer Praxis, Springer, Berlin Heidelberg, 6787, 2006.

Wang, B., Clemens, S. C., and Liu, P.: Contrasting the Indian and East Asian monsoons: implications on geologic timescales, Mar. Geol., 201, 5-21, 2003.

Wang, Y., Cheng, H., Edwards, R. L., Kong, X., Shao, X., Chen, S., Wu, J., Jiang, X., Wang, X., and An, Z.: Millenial- and orbital-scale changes in the East Asian monsoon over the past 224000 years, Science, 451, 1090-1093, 2008.
Webster, P. J.: The coupled monsoon system, in: The Asian Monsoon, edited by: Wang, B., Springer Praxis, Springer, Berlin Heidelberg, 3-66, 2006.

Wu, N., Pei, Y. P., Lu, H. Y., Guo, Z. T., Li, F., and Liu, T. S.: Marked ecological shifts during 6.2-2.4 Ma revealed by a terrestrial molluscan record from the Chinese Red Clay Formation and implication for palaeoclimatic evolution, Palaeogeogr., Palaeoclimatol., Palaeoecol., 233, 287-299, 2006.

Wu, N., Chen, X., Rousseau, D. D., Li, F. J., Pei, Y. P., and Wu, B.: Climatic conditions recorded by terrestrial mollusk assemblages in the Chinese Loess Plateau during marine oxygen isotope stages 12-10, Quaternary Sci. Rev., 26, 1884-1896, 2007.

Wu, N. Q., Rousseau, D. D., and Liu, D. S.: Land mollusk records from the Luochuan loess sequence and their paleoenvironmental significance, Sci. China Ser. D., 39, 494-502, 1996.

Wu, N. Q., Rousseau, D. D., Liu, T. S., Lu, H. Y., Gu, Z. Y., Guo, Z. T., and Jiang, W. Y.: Orbital forcing of terrestrial mollusks and climatic changes from the Loess Plateau of China during the past 350 ka, J. Geophys. Res.-Atmos., 106, 20045-20054, 2001.

Xiao, J., Porter, S. C., An, Z., Kumai, H., and Yoshikawa, S.: Grain size of quartz as an indicator of winter monsoon strength on the Loess Plateau of Central China during the last 130000 Yr, Quaternary Res., 43, 22-29, 1995.

Yen, T. C.: Die chinesischen Land- und Süsswasser-Gastropoden des Natur-Museums Senckenberg, Abhandlungen der senckenbergischen naturforschenden Gesellschaft, 444, 1-233, 1939.

Yin, Q., Berger, A., Driesschaert, E., Goosse, H., Loutre, M. F., and Crucifix, M.: The Eurasian ice sheet reinforces the East Asian summer monsoon during the interglacials 500000 years ago, Clim. Past, 4, 79-90, 2008, http://www.clim-past.net/4/79/2008/.

Zhou, L. P., Oldfield, F., Wintle, A. G., Robinson, S. G., and Wang, J. T.: Partly pedogenetic origin of magnetic variations in Chinese loess, Nature, 346, 737-739, 1990. 